\title{
THE SYMBOLIC LANGUAGE OF MIRROR IN THE MYSTICAL POEMS AND THE REFLECTION IN ISLAMIC ART
}

\author{
Golnar Alibabaei \\ Instructor of Alborz Technical and Vocational University, Karaj, Iran
}

\begin{abstract}
As a symbol and mystery, a mirror has been widely used in the work of mystic poets of Iran. From the mystics' point of view, the universe, in all of its overt and covert manifestations, is nothing but a mirror of God. The art of Islam, where God's existential appearances exist, wishes to reflect the mirror's mystery. The present article aimed at finding out the symbolic presence of mirrors in mystical poems and how it is reflected in Islamic art. The research is conducted through descriptive-analytical method and seeks to answer the question: What are the themes of the mirror symbol in mystical poems and why does it appear in Islamic art? Hence, using the method of gathering library information and electronic resources, the findings show that the artistry of the Iranian poets regarding the concept of the word mirror in terms of the unity of the essence of Haq Ta'ala and human's life is entirely associated to the pantheism of universe. A mirror that has manifested its inner meaning in Islamic art. These aspects in the perfect human being's life, whose origin is the light of all lights, are a reflection of thousand and a one God's attributes. They have been mirrored the world and have been manifested in various forms in Islamic art. This is a kind of mirror of the beauty of truth.
\end{abstract}

Keywords: symbolism, mirror symbol, mystical poems, Islamic art

DOI: https//doi.org/10.3176/tr.2021.2.03

Received 20 March 2020, accepted 9 November 2020, printed and available online 10 June 2021 


\section{Introduction}

The most basic aspect of the mirror is appearing. Mirror as a brilliant tool displays the face and appearance of every individual to him or her, it reflects the light and it is lit without having any light by itself. These two important features cause the mirror to have a great effect on the human spirit and subconscious, up to the point that it can reflect divine attributes. The poets of Persia have created mystical themes, inspired by the sincerity, brilliance, honesty of the image and other characteristics of the mirror.

Mirror was normally used by its real meaning by Persian poems, however with the prevalence of Sophistic beliefs in the Persian poems since 6th century, mirror contributes to the new themes in which the glossy and sincere nature of mirror indicates refining the soul and it is considered as a symbol of mystic's heart, in other words 'mirror' has a fixed and certain role in the Persian love poems, that is related to the dreaming power and artistic awareness of the poet. The symbol supports a wise life that takes the hand of sense, heart, thought and soul of human and takes him or her up to the borders of excellency, then finally refrains humbly and courteously.

In this level, Allah himself teaches and himself gets things (the truth) be learnt from bottom of heart. The mystics consider the things and the whole world like a mirror and know the world of contradictions under the governing of the unique God and to look at the truths of the world with edification. The mirror is the symbol of purity and brilliance of the human soul as Hafez the great poet has said in his Ghazal no. 320 , "Thou the drinker of the king's party, have no hatred in heart, as it is a magical mirror to show the world's every part."

In this regard if a human's cup of existence is lit by the light of awareness and wisdom, and the heart is refined from the color of duplicity and becomes clear, everything will be mirror-like in the thoughts of the follower and will reflect the unique truth. It seems this has been reflected in the Islamic art. This reflection can be observed in symmetricity of pottery motifs, calligraphy, carpet motifs, Tazhib, and especially Islamic painting and architecture. Some pictures with frames inside, with a mirror-like rhythm - as if various times are mixed - display several manners and times simultaneously. This trend has existed as a model in the mirror-work of Islamic architecture and as an ornamental aspect has displayed the mystical feature of the mirror to show various things with various images, therefor the present research intends to discover if the mystical approach of poets toward the mirror's nature and secret have been reflected in the Islamic art and the mystical role of mirror in this art? Since no such a research has been carried out before, the present research is considered significant, from the point of view of mystical theme of mirror and its reflection in the Islamic art, point of view. 


\section{The research method}

The present research has been carried out by a descriptive-analytical method accompanied by library study and utilizing electronic resources. The present research has been compared with several samples of mystical poems with the theme of mirror and paintings of Islamic art, from the mystical aspects of mirror points of view. Also, some paintings and mirror-work of Imam Reza, Hazrat-e-Masoume and Shahe-cheragh holy shrines have been studied to observe the harmony between the mirror theme in mystical poems and nature of mirror-work art in Islamic art of Iran.

\section{Research history}

The study about mirror, in papers such as "Mirror and Harp in Molana's speech" by Maryam Mosharraf (2004), published in the magazine called "The Persian Language \& Literature" reviewed the symbolic application of the mirror in the Molana's poems and also the paper "The Unity in Existence: Experience, Interpretation, Exemplification" by Ghasim Kakayi (2001), published in the quarterly magazine of "Religious Thoughts" analyzed the relation between the experience and interpretation of the unity in existence with the mystics' world of exemplifications.

"The appearance of the mirror in the mystical literature", a paper by Ghadamali Sarrami (2009), published in the exclusive quarterly publication of mystics, "The symbol of mirror in Molana's speech" a paper by Amin Roshan (2007) published in the "Religions \& Mystics" has reviewed the mirror symbol as the expression of divine secrets in Molana's poems. Books such as "The conquest of Mecca" by Ebn e Arabi, has dealt a lot with the unity of existence and exemplification.

The book "Endless secrets of the mirror" by Ali Babaei (2011) from Mola publications has dealt with the secrets of mirror in the world of cognition, wisdom and Mystics. Papers such as "Brilliant vision in the contemporary illustration", by Marjan Mortazavi and Khashayar Ghazizadeh (2010), printed in "Negareh" magazine, have given a classification to brilliant vision in illustration. "Comparative study of visual indicators in Iranian mirror-work and art of photo collage", by Reza Pourzarrin and Asghar Javani (2014) was published in the Fine arts gazette dealt with similarity between the aesthetic indicators between mirror-work and photo-collages.

Another paper is "The review of Mirror-work art wisdom in the Islamic architecture" by Nahid Taghavi (2015). In the first International Conference on Human, Architecture, Civil Engineering and City which dealt with mirror-work among the modern architectural elements, and lastly was the book called "Islamic architectures ornaments" by Mohamad Yusef kiani (1997) from Miras-e-farhangi publication which defined the position of "Mirror" in architecture. 


\section{Semiotics \& understanding the symbols in the literature}

A symbol means the representative and appearing (Dehkhoda dictionary 1995: 77). It is a secret word, pointing, mystery, hint, enigma, indicator, covert cue, special indicator from which something is understood (Pournamdarian 1995: 1). The word 'Namad' together with the secret and embodiment are equivalents for the word 'symbol' (Hosseini 1990: 39), Symbolism is blending the two worlds of Sensible and Divine in the artistic embodiment (Sarfi 2003: 177). The extreme symbolism in its nature is a kind of belief in the other world (Pournamdarian 1985: 10).

The mystical poems also have deep extreme symbolism, as the mystics believe that everything in the sensible world has a divine principle and eternal model, the materialistic world is a presentation or a shade of the spiritual world (Sarfi 2003: 166).

\section{Mirror symbol}

Mirror is a reputable symbol in the world. In Plato's 10th book of The Republic, Socrates defines art as a mirror that reflects the real world. To Plato's opinion, as the world is like a mirror to reflect the truths of the Mesal world (imaginational world), Art is like a mirror to show the facts of the real world (Mosharraf 2004: 82).

The exemplification of the mirror of which the first written form was transferred to us via Plato's works, was completed in the following centuries by another philosopher called Plotinus. He was an heir to the Plato's idealistic philosophy, with intuition themes put an artistic color to Plato's beliefs, and made it increasingly apt for developing mystical language and viewpoints (Mosharraf 2004: 83). Borkhart adopted 'mirror', among the rich treasure of symbols and secrets of mysticism. To him, mirror was more appropriate than any other symbol to define the nature of mysticism and its cognitive characteristic (Kamalizadeh 2013: 77). to clarify this by going through the mirror entries, we review its mystical inside.

\section{The reflection}

In the poets' mystical speech, mirror can be symbol of three things: the mirror to the people, the mirror to Allah and mirror to oneself, also ones' heart at the mirrorlike level is ready to accept the oracular forms (Mosharraf 2004: 98). Omran Sabi in a debate with Imam Reza says (Towhid Sadoogh: 434-435): if you learn about the holy nature of the creator by looking at the creature, then either of them shall be inside the other, and as this is impossible for them to enter the other therefore this reasoning is not utilizable for proving the existence of creator.

Imam argues that neither of them enters the other. However, you see yourself in the mirror and it shows you despite the fact that neither you are in the mirror nor it is inside you, so how is it you recognize yourself in the mirror. Omran responds "by 
the light that is situated between me and the mirror". The meaning of mirror in the mystics is the form of 'mirror' as the nature of it (Nasiri 2010: 35-36). The reflection means that what exist in the origin, is re-displayed in the mirror of self, such as appearing of the image in the mirror, self is a means of observing the faces against the existing origins. Hafez has a nice poem about the reflection:

the beauty of your face as reflected in the mirror, created numerous pictures in the mirror of my dreams all the beauty of the sweetheart's image, is a glow of the cupbearer's face reflected on the wine (Hafez book of poems, ghazal no.111)

The mystical aspect of reflection embodies forms such as the human face through the light of forms, in fact presents a symmetric and corresponding aspect as a hint to find out about the light. Reflection is in fact the symmetricity made possible via the mirror and light in order for the spectator to observe another form of the thing in the mirror.

Shahab-eddin Sohrevardi in the Wisdom of Khosravani, p. 44 believes that the divine beauty by its nature intends to display its face in the world's mirror, therefor the world is in fact same as "Negar" or the image of the eternal beauty (Sarrami 2009: 50).

Any scientific encounter with the world's phenomena means as if its picture is taken and its lights is collected in oneself. Since the phenomena are the God's status therefor any such picturing would be equivalent to collecting the God's status and lights hence, one would possess every status and highly feelings. Such a person would be considered a perfect human or the best "Mirror of the God's nature" (Babaei 2012: 95).

The God made every particle of the world a mirror,

To reflect his own image on every one of them

Anything looking beautiful in your eyes,

Is in fact an image of God if you look carefully

(Haft Orang, p 652).

\section{The dream-like forms}

The image or the dream-like aspect of mirror is the reflection of Plato's belief which considers this world a reflection of world of the Truths (Mosharraf 2004: 82).

As Mirfendereski Mystic 11th AH, says: "everything on the top has got a face beneath". The image in the water or flat mirror or any kind of mirror is a secret of relation between the truths and the 'Raghayegh' or dripped gist of the truths (Babaei 2012: 42-43). the mirror is merely the symbol or the apparent place of exposure which situates opposite to them, the truth of this form belongs to the 'Mesal world'. 
Dream is the imaginary form or face in the eye of the dreamer ... man's dreaming ability resembles a mirror which reflects the forms of the Mesal world (Khoshnazar et al. 2010: 11).

Present yourself to my heart, as huge as you can, The house of mirror is big enough for any image (Saeb book of poems, ghazal no.1298)

The mirror and the appearance forms are so important in the epistemology that Henry Carbon considers the dream science the same as the science of mirrors or learning about all the mirror-like surfaces the evolving forms inside them (Kamalizadeh 2013: 79). Ebn-e-arabi considers the world as imagination in the imagination, the example for this can be the forming of image in two opposite mirrors, each one shows the other together with its images, and hence these would be endless. He states that the world is the mirror to God's image, and God is the mirror to the perfect human. A look is displayed in the mirror and in turn this is shown in the opposite mirror. God observed himself in the people and saw people in the divine mirror ... This is close to the imaginational highness (Kakayi 2001: 98 -99).

The dreams that trap the great men are the image of divine gardens' beauties (Masnavi Manavi, 1st chapter, verse no.72)

\section{Mashhoud (the beheld)}

Obvious, visible, approved (Dehkhoda dictionary 1995: 77). The mirror must be flat, smooth and brilliant in order to display others and neglect the owner of the image as it is, in the same way a mystic shall purify his heart and soul in order to be the reflection of God (Kakayi 2001: 99).

My heart has purified my thoughts, so as to receive novel images in the heart's mirror anyone born from a good father, shall be placed before the mirror, A nice face loves the mirror, it would refresh your life and boost your heart (Masnavi, 1st chapter, verses no. 3154-3156)

In the idea of Ebn-e-arabi about the unity of existence, the world is the reflection of God, and in fact God appears in the face of the world (Sarrami 2009: 51).

The issue of mirror-like world roots in this idea, as the mystics who believe in unity consider the eternal lover, as Attar Nayshabouri says: 
I have seen your perfect appearance everything I found in that mirror there was 100 thousand signs

(Attar. Book of poems, p 418-419) as if I have observed both worlds in the mirror I saw the mirror itself to be hidden shown in mirror however, I saw no sign of the mirror

Mirror is the closet symbol of spiritual observance and is in fact mysticism in whole, as it shows the unity of the beholder and the beheld. The secret of mirror is as clarifier as the mirror itself and it is the clear reflection of imagination and dream power (Kamalizadeh 2013: 77). Ebn-e-arabi interpreted the below Quran verse 88, Surat al-Qasas, says:

$$
\text { "كل شىء هالك الا وجهه له الحكم و اليه ترجعون"، }
$$

God said: verdict is what appears in the same objects, then: you go back from anything else to God (Kakayi 2001:103). This famous mystic in "fotouhat of Makkieh, Vol 4, p.105" says: God is appeared, beheld and visible, also God is inside not beheld and not visible (Kakayi 2001: 105). This speech is similar to the Ayeh no. 3 of surat Hadid as it says: God is the first and the last, both the appearance and the inside.

do not neglect unity because of its multiplicity, Bidel

Imagination, has it the mirrors in front of the lonely person

(Bidel 2007, vol.1: 118).

The followers (sahabe) of Rasoul-at-Allah asked him to inform us of the beholder who is Mohammad and beheld meaning; he said beholder is Mohammad and beheld is the resurrection day. Mohammad "I sent you a beholder, encourager and warning giver", and also "on that day all people gather for you and that is the beheld day!"

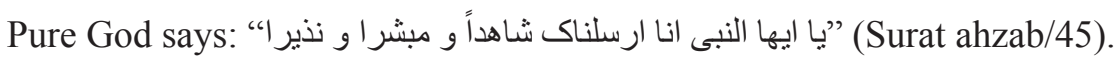

"ذلك يوم مجمو عله الناس و ذلنى يوم مشهود" (Surat Hood /103).

Ebn-e-arabi considers man a connecting ring and identifying factor in the reflector process, for it is both the representative of the mirror and also an agent of the beheld. The mirror is a symbol of reflectivity of the beheld object's nature and the beholder id Allah, therefor Ebn-e-arabi considers the human as the same "Like as reflection principle" (Khalil-allahi, Borjsaz 2011: 53).

You are the eternal beholder and the beheld, you smile at the path, the seeker and the Journey

(Divan-e-shams, ghazal no. 2868) 


\section{Mystical poems}

The mystical poems fall in the category of the love poems and they are not considered an independent type, as love poem's definition matches the mystical poems. Love poems deal with emotions and this can be found in mystical poems from literal and artistic point of view (Tadayyon 2015: 40). Persian mystics in various formats made Persian poem the pioneer of the world. As mirror to life, according to the impression of this mysticism, only through making a mirror out of one's own stone (heart), one can sit before the sweetheart's (God) face and observe his image dancing inside the life's pure wine (Sarrami 2009: 36). Najmeddin Razi says: one's self is the heart of mirror and both worlds are the frame of that mirror and all the perfection and glorious features of God are realized through this as it is said in the below Quran Ayeh:

$$
\text { "سنريهم آياتنا فى الافاق و فى انفسهم" (Surat Fussilat /53). }
$$

We will see our signs in the horizons and in their selves (Razi 1933: 3). The mirror-like nature of life has been reflected in the works of Attar, Molana (Rumi)'s Divan-e-shams and Masnavi, Hfez, Khaghani, Saeb Tabrizi, Bidel Dehlavi and Jami etc. and mirror has been used by them mystically.

\section{Mirror from the mystic poet's viewpoint}

Molana considers the world and eternal life as a mirror to the divine nature, God as the mirror to the observation of creatures and their lives. This is an example in the Jameh al-Saghir, vol. 2, p. 170 for the saying: "a believer is a mirror to the believers". Rumi's intention by the first believer is the holy entity of God which is one of the excellent names (Asma-al-hosna), and the other is a believing creature who acts as a mirror to attract God's light (Roshan 2007: 113).

One who has no color (trick), becomes a mirror to divine patterns he will believe in our secret with no doubt, a believer is a mirror to other believers (Masnavi, 1st chapter, verses no. 3146-3147)

Some of the mystics know mirror as a symbol of the heart and combinations such as, 'life mirror', 'eye mirror'. All the seven faces of heart of the beholder receive the divine lights especially the 7th face for which, the author of "Mersad-ol-ebad" says: "the seventh, is Top Secret and heart which is the mine of divine features that are reflected there and that is a sign of human esteem". 
The brilliance of mirror is description of hearts, it accounts for the endless images (of God)

(Masnavi, 1st chapter, verse No. 3485)

Molana believes that the mirrors which have not become pure are selfless (mokhless) and as they become from a piece of iron to a clear mirror they get to the degree of liberated (mokhlas) persons who are free from sins' traps as Rumi says in his 2 nd chapter of Masnavi:

Mirror is not pure, however it is selfless

he who has not got the bird, is imperfect yet

when a selfless one escapes the world, he becomes freed

he is freed again when he gets into the safe status

(verses no. 1315-1316)

The mirror is symbol of a perfect human and a true believer in the idea of the mystic, clear and free from any stains, the image of divine secrets and oracular world has appeared in him (Roshan 2007: 115-116). This mirror is the life of the perfect human or the mystic in which the truths of the world are reflected, and anybody can see the reflection of his subconscious inside it (Mosharraf 2004: 93).

This is like pictures however it is not a picture, in the example picture of God can be seen

(Masnavi, 6th chapter, verse no. 3190)

Hafez the great poet and mystic, whose mystical poems have presented the glorious beauty of God using examples and the symbol of mirror and has considered the secret of mirror like the magical mirror (Jame-Jam which displays anything in world) and has showed the truth of world inside it. Hafez has considered the beauty of the world a result of divine light reflected on the world mirror, and has said:

From now on my face will be reflected in the mirror which divine beauty is displayed there (Hafez book, Ghazal no.183).

Mystical thoughts consider the world, with all its diversity and colorfulness, as only one heavenly manifestation and divine light that has reached the stage of emergence. Hafez has got inspiration from mirror-like themes and has dressed it with his magical art:

Before my hearts mirror, whatever I put it merely displays the dream of your beauty

(Hafez book, Ghazal no. 261) 
In the mystical notions, what makes the heart deserving the level of mirror-like or Jame-Jahanbin that can reflect anything in the world, in the world is the light that glows on the heart and its source is the Noor-al-anvar or the original light that was gifted in man's sub-conscious from the first day. Heart is made of light and due to this fact, God created a thousand and one mirrors to reflect every divine feature, and also to display beauty of the truth (Sarrami 2009: 67-68), as Hafez says in his ghazal no. 361 :

The old man in the tavern gave me the magical mirror at dawn, and in that mirror I observed the image of your beauty.

The perfection of mysticism is the cognition of the mirror-like aspects of the world, in other words those who are looking for the truth as long as they have not purified themselves and have not became clear and brilliant like a mirror, they will not see the world as a mirror to the beauty of truth therefor secret of reaching this level is avoiding the darkness and attaching to the purity and beauties.

You may see the god's light when,

Your heart becomes clear and sincere

(Khaghani 2009: 813)

\section{The mirror-likeness in the Islamic art}

Islamic art is based on Islamic features and is also result of a civilization created during several centuries in Islam territory from India to Spain with the artistic traditions. Islamic art has spiritual nature and not only in its most obvious symbol that are mosques, but also in calligraphy, decorative arts and pictorial arts. This art is more of Monotheism spirit of Muslims in abstract formats than Contain merely religious themes (Pakbaz 2014: 725).

From Islam's point of view, as it is said in the Quran Ayeh no.24 "Allah is the illustrator artist" (Ho allah al-Khaleq al-Bari al-Mosawwer of surat Hashar), art is more than anything else demonstration of divine unity in the beauty and discipline of the world. The unity is reflected in harmony and cohesion of the pluralist world. The Jamal (beauty) itself has all these features. Concluding the unity from the beauty of the world is the perfect wisdom, art is fundamentally based on the wisdom or science. The aim of art is the discipline which demonstrates the divine unity in the most direct way (Burckhardt 1990: 12).

God is the real artist who appears in the world and all creatures in the endless world are signs of God's names and features. The divine names appear in the world's creatures; however, they are still covert in them. God appears in the revealed truths of world, yet he is hidden and convert. As it is said in the Quran Ayeh no. 3 of surat Hadid:

$$
\text { “"هو الاول و الاخر و الظاهر و الباطن" }
$$


The Muslim artist also as a sign of God's name creates a piece of art to demonstrate the divine unity. The approach as a pure representative serves the Islamic art to reflect the Islamic idea. The applied arts such as pottery, metalwork, rugs, textile, calligraphy, Tazhib, Tash'eer and Islamic architecture show this art. In the continuation of the research we deal with the mystical aspects of mirror and its appearance in the arts.

\section{Pottery and metalwork}

Pottery motifs have been a source of inspiration for the artist. This art is one of most obvious symbols of Islamic art which deals with Muslim beliefs and their image of the world by its various forms and motifs. The pottery maker utilizes the symbols, originally and spiritually to act as medium for travelling from inside to the appearance and demonstrate a feature of the god features. He uses human motifs on the pottery to create special atmosphere and remind his eternal divine status (Fig. 1). This mystical worldview helps people to show divine status of humans and according to Ebn-e-arabi a human being is the embodiment of God's reflection. The designs of Islamic pottery use reflection and symmetric aspect of mirror and motifs are situated opposite each other as if reflected inside each other via a mirror.

he will believe in our secret with no doubt a believer is a mirror to other believers (Masnavi, 1st chapter, verse no. 3147)

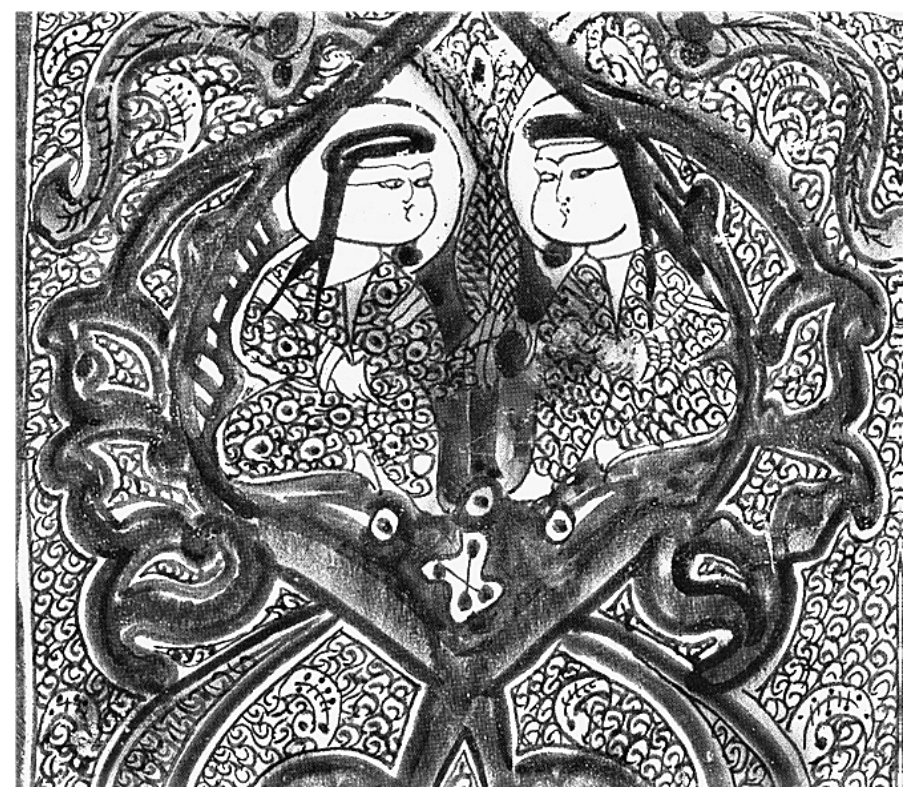

Figure 1. Saljoughi pottery, 6th century. Source: Fehervari 2000. 


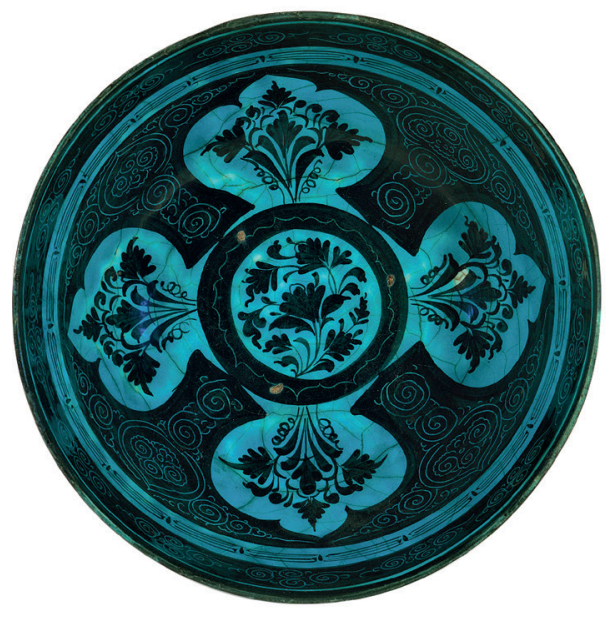

Figure 2. Pottery bowl, 9th century. Source: www.metmeusum.org.

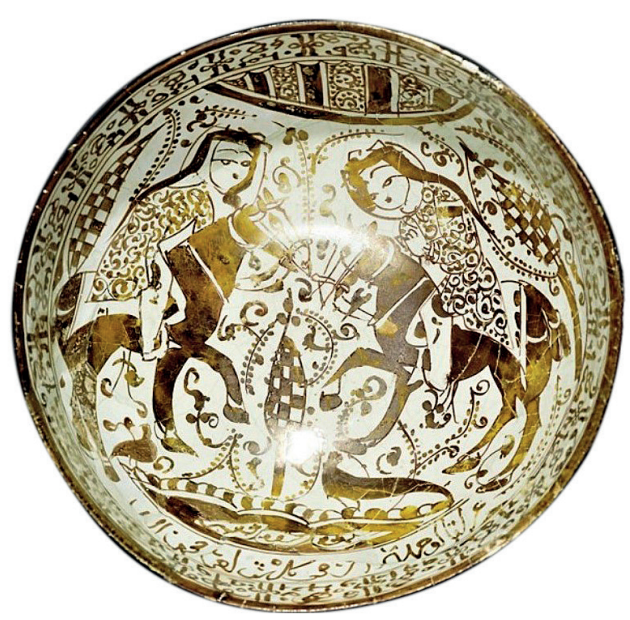

Figure 3. Golden pottery, 6th century. Source: Fehervari 2000.

In Fig. 2, a hemispherical bowl plant has motifs against black background and bright turquoise enamel has covered all the bowl. The plant motif with intricate and spiral patterns is repeated like a mirror and is reflected symmetrically on all four sides of the bowl.

In Fig. 3, two horse riders are designed opposite each other and symmetrical as if the bowl was divided into two halves and a reflection of one is seen in the other. Also in the metalwork, the mirror example is used and in the engraved motifs on the wares, symmetry is shown in Fig. 4, the Sphinx design with Slavic motifs is painted in the corner and is mirrored all around the ware.
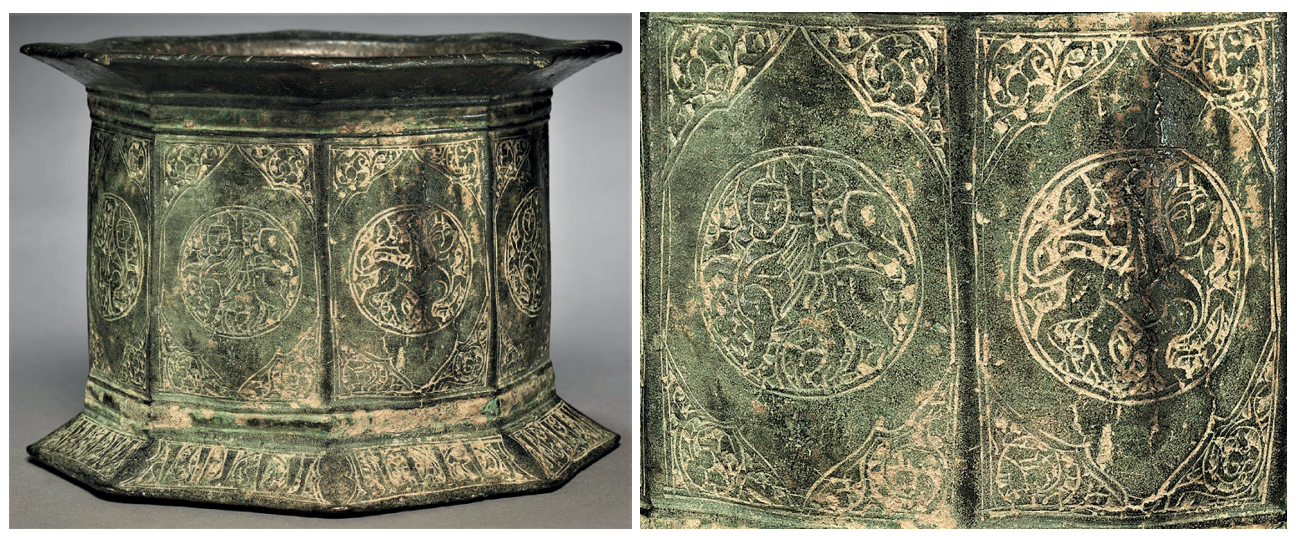

Figure 4. Saljoughi Bronze ware, 6th century.

Close view of Sphinx on bronze wares. Source: www.clevelandart.org/art/1992.190. 

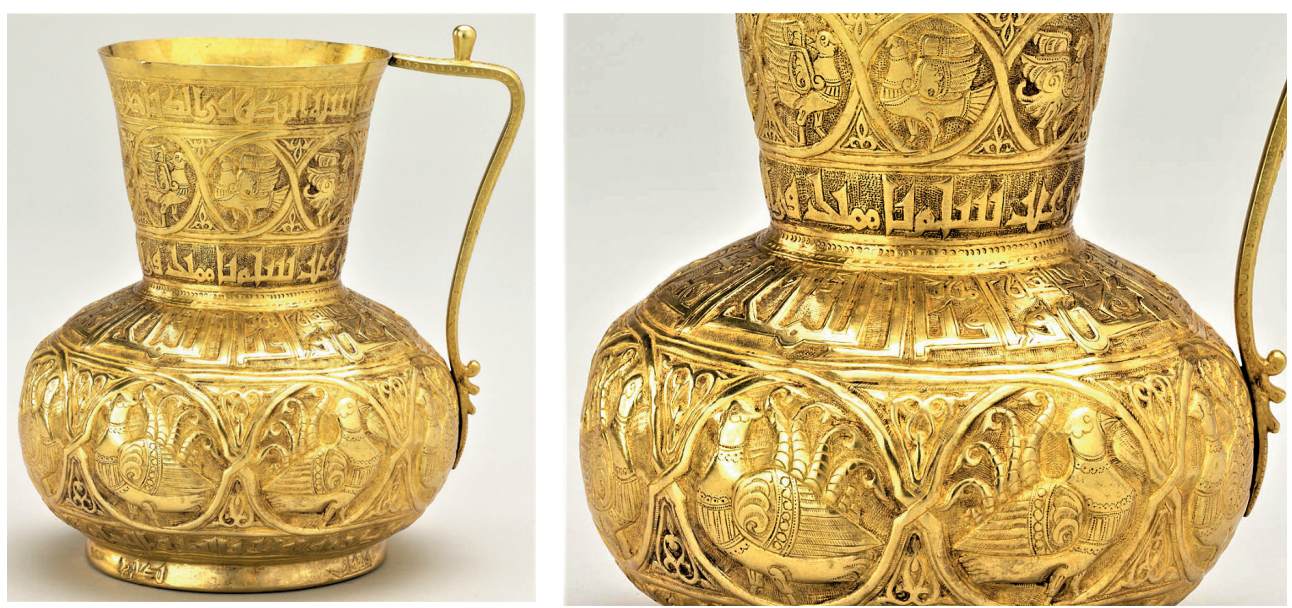

Figure 5. Golden jar, Persia or Iraq, 985-998 AD.

Close view of a symmetric bird on the gold jar. Source: www.clevelandart.org/art/1966.22.

In Fig. 5, two birds are reflected in the upper and lower stripes in the middle of a pottery jar from Islamic era using symmetry to display the bird motif around the jar.

\section{Rug-weaving and textiles}

The motifs in Persian carpets other than aesthetical values, have excellent meanings, therefor many of such motifs are symbols of an object used in daily life and refers to its internal meaning. Carpet design, also similar to pottery have used various human, animal and plant motifs, thanks to perfect Iranian designers, they are reflection of unity in plurality and also appearance of plurality in unity which are among the mystical aspects of mirror (Fig. 6 and Fig. 7).

This valuable art has included the reflection and symmetric features of mirror inside as it has displayed symmetric motifs in a mirror-like form opposite each other.

The textile especially in the Saljoughi era, has reached application of symmetric motifs in textile to a climax. In (Fig. 8), two angels at the sides of a cedar tree which is symbol of eternal life, are painted. The motif of these two young men is designed inside a medallion with the form of eye-tear, while they have put hands under chins and are considered symbols of eternity which is the reward of prosperous men in paradise, it seems that the left-hand man is mirrored by the right-hand man and they provide reflection of each-other's inside.

The beautiful, are like the mirror for his beauty

their love is the reflection of his perfection

(Masnavi, 6th chapter, verse no. 3181) 


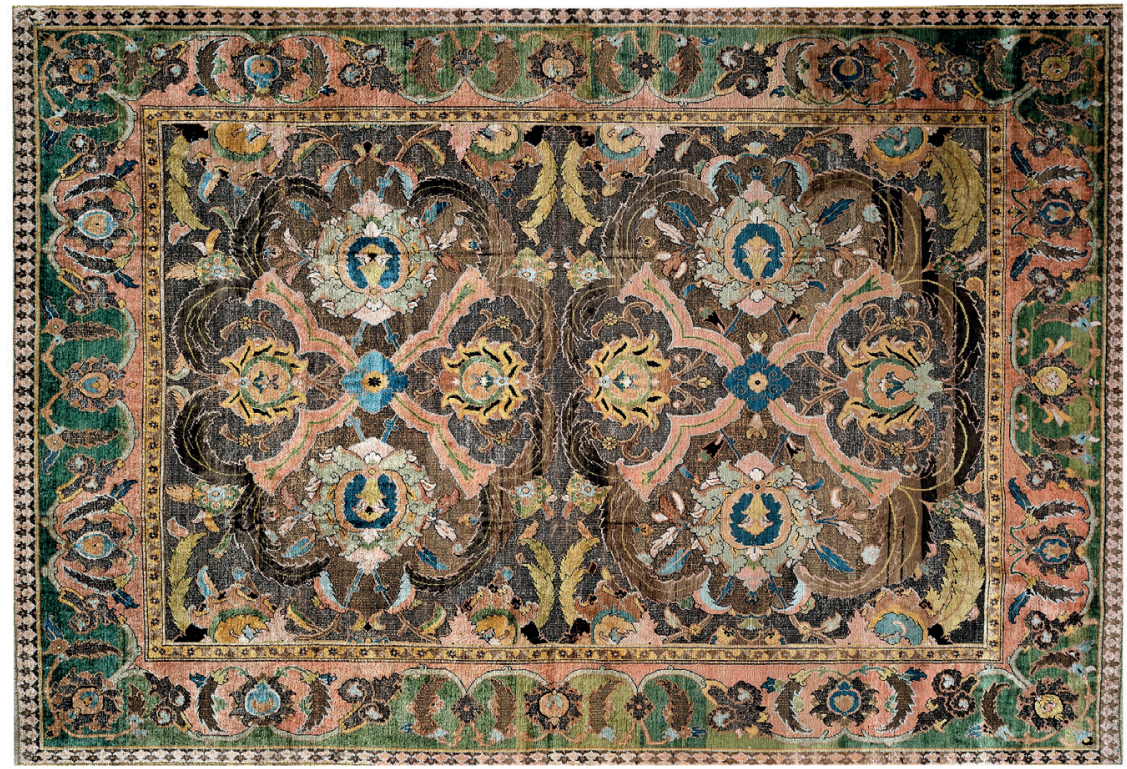

Figure 6. Persian rug, 11th century. Safavid era. Source: www.clevelandart.org/art/1926.553.

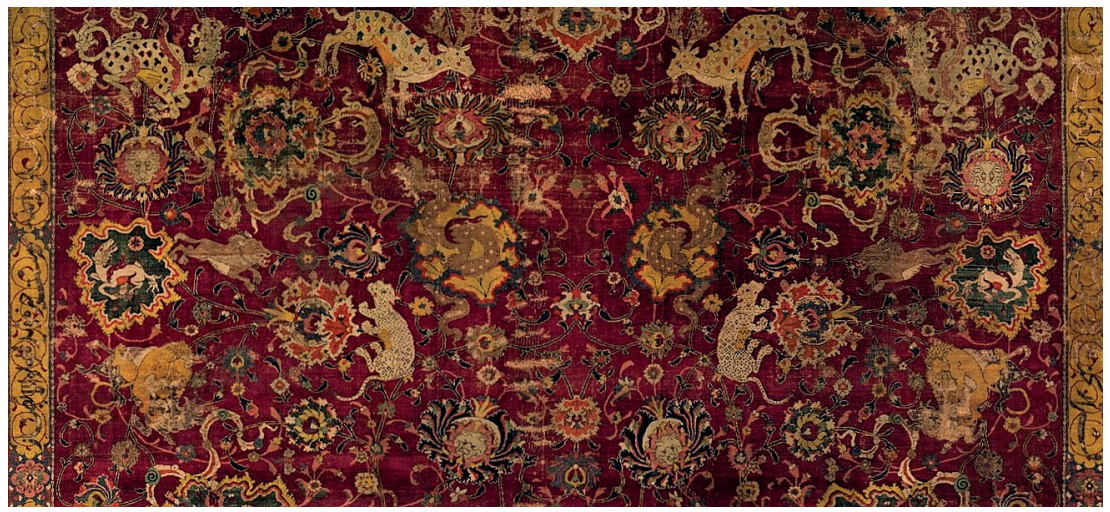

Figure 7. Silk carpet with plant and animal motifs, 16th century. Safavid era. Source: www.meusum.org.

The Saljoughi silk cloth with motifs of animals such as rams or lions are woven by golden threads around an embossed tree in the center of a circle and surrounded by animal motifs and inscription, in an endless way (Fig. 9).

This repetition and symmetry in design emphasize the mirror-likeness of motifs. In Fig. 10, the motif of a duck and Khataie flower is repeated in a way that the viewer's eye is put in a labyrinth inside a horizontal and vertical mirror to reflect the motif like this. Similar symmetry is even continued in the Kofi calligraphy around the duck motif and pulls the tree between the design and circle toward the infinity. 


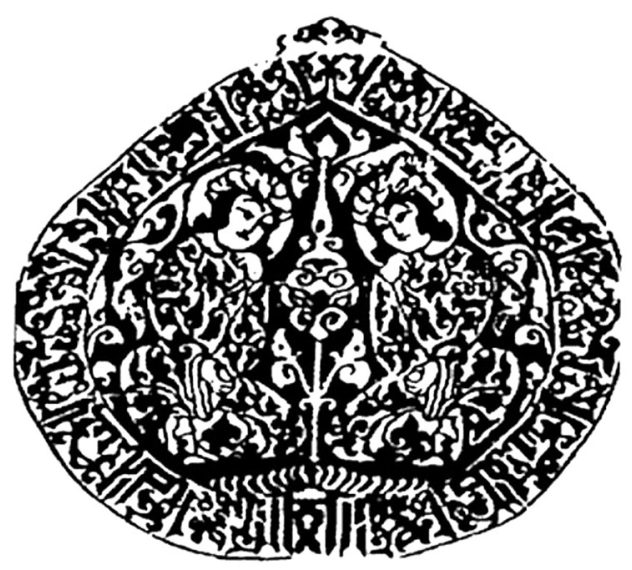

Figure 8. Fabric with angels' motif, 6th century.

Source: Pope 2008, p.137.

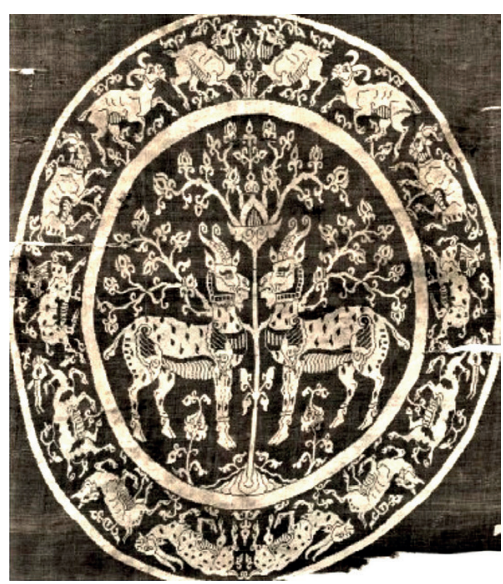

Figure 9. Silk, 5th century.

Source: www.clevelandart.org/art/1955.52

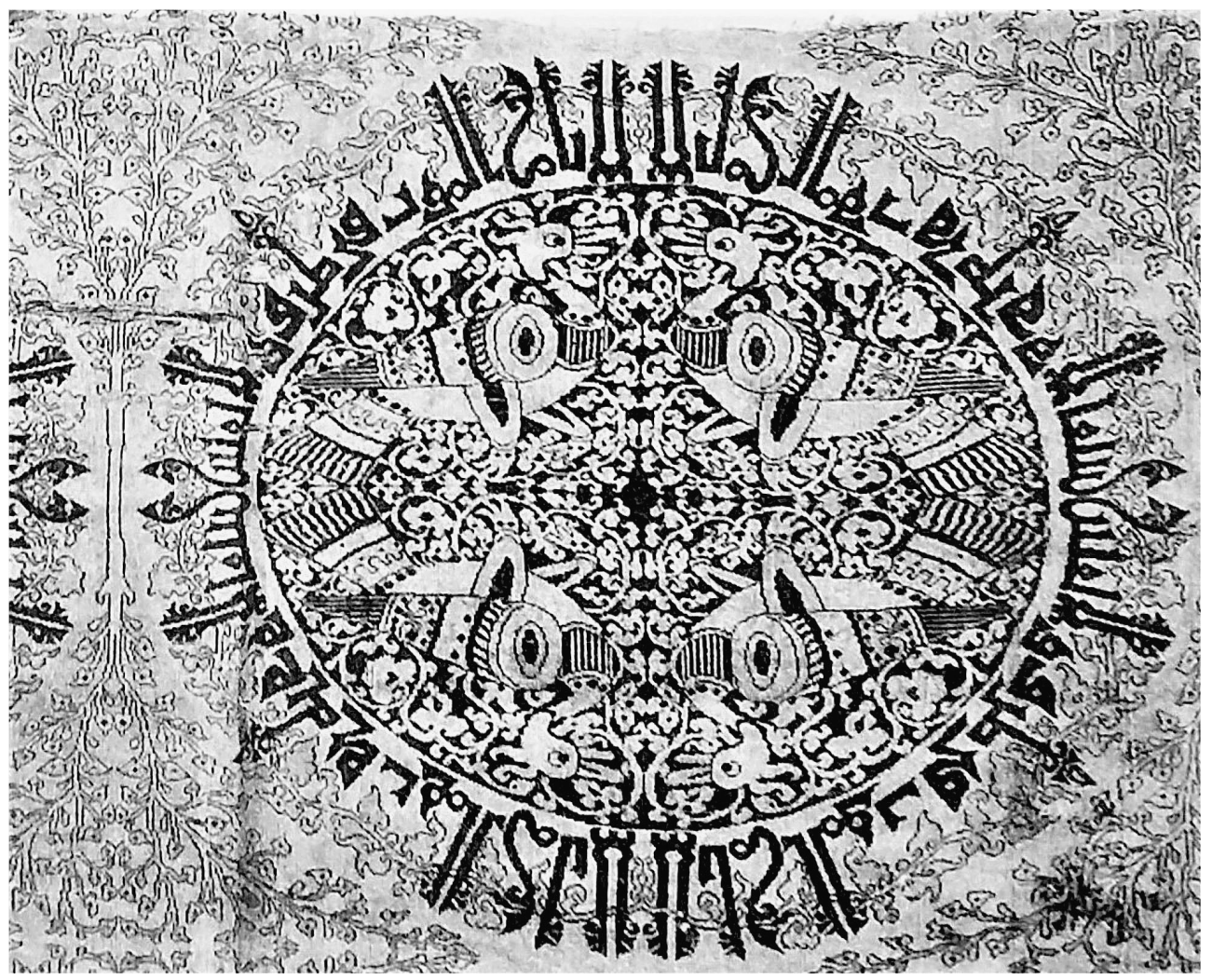

Figure 10. Silk and wool, 6th century. Weaving, Museum of Columbia State.

Source: Pope 2008, p.137. 


\section{Calligraphy and inscriptions}

Calligraphy is considered the most excellent Islamic art and Muslims have always respected it as they knew it as a means to display divine words. They used nice handwriting, not only in the Quran, but also in other arts. Islamic calligraphy that reached aesthetic perfection was placed as an axis among other visual arts (Pakbaz 2014: 207).

From Islamic calligrapher's point of view, the first perfect handwriting belonged to Aliebn abitaleb (peace be upon him) handwriting that attracted readers of insight toward the divine words, was Kofi type (Monshi Qomi 1973: 13). This type was used in religious buildings in the method of bannayi, which is known as Kofi bannayi. The west terrace of the Jameh mosque of Isfahan shows some prayers to God in beautiful Kofi type. These two inscriptions are face to face as reflected in the mirror (Fig. 11 and Fig. 12), the northern inscription writing is:

$$
\text { "سبحان الله و الحمدالله ولا اله الا الله و الله اكبر“" }
$$

The whole sentence is freely divided in the inscription space and in an ordered combination that the viewer's eye only sees a labyrinth of geometrical forms including abstract ones but it is not limited to that. Holy words for praying to God are placed in a cover of material and motif and color (Halimi 2011: 138-139).

Whatever beauty in her is God's image

Like the moon's picture in Stream water

(Masnavi, 6th chapter, verse no. 3139)

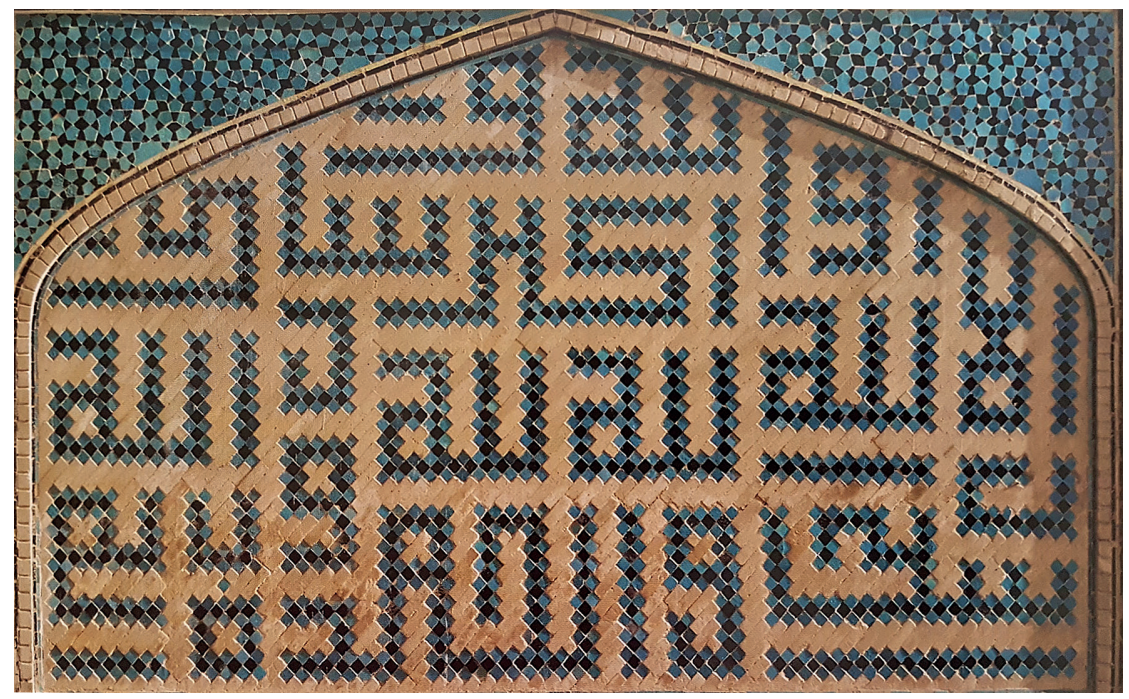

Figure 11. Inscription, Isfahan Masjed Jameh, West terrace, North side inscription. Sourc: Halimi 2011: 138. 


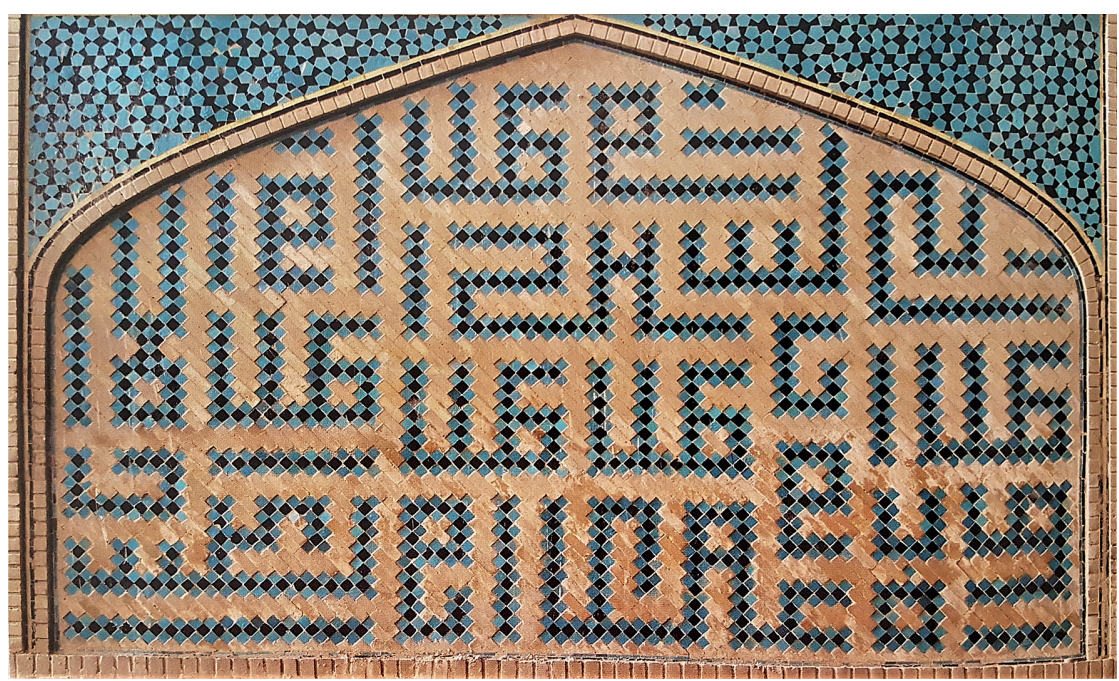

Figure 12. Inscription, Isfahan Masjed Jameh, West terrace, South side inscription.

Source: Halimi 2011: 139.

\section{Tazhib and Tash'eer}

The art of Tazhib like Quran itself has different inside and outside and it is mainly made up of abstract shapes with pure colors that are pleasant to look at. However, to understand the inside, one has to find out about the beauty beyond the motifs and shapes. Shamseh in Islamic art is a symbol of a prophet and its spiritual position as a perfect human. Shamseh motif (Fig. 13) based on Ayeh no.35 of Sooreh Noor (Allah is the light of sky and Earth) is a sign of holiness and unity of God.

One of the mystical aspects of it is a perfect human or an image of God, as Ebn-earabi says, "world is mirror of God and God is mirror of perfect man", so aspects of plurality in shamseh with their harmony move toward unity like a mirror as it shows the face of a perfect human in an eternal form. In this motif also symmetry is an obvious aspect of Shamseh which has made every motif as a component mirror-like in itself. Jami in Haft-orang says:

\section{God made mirrors from every particle of world, and reflected his own image on every mirror to your precise eye whatever seems nice, is the Gods picture, if you look carefully}

Tash'eer is an art of decorative array with human and plant motifs used frequently in the manuscripts especially in Safavid era, the climax of this art. The mirror-like aspect of decorative motifs can be seen in some of khamsah tahmasbi manuscript pages, for instance in Figures 14 and 15, these animal and plant motifs with a vertical symmetry have made a mutual reflection show unity while there is plurality. 
Figure f.17r shows two pheasants sitting opposite and back-to-back of each other with some distance on the plants' branches and repeated symmetric Khataie motifs. Figure f. $17 \mathrm{v}$ shows twisting plants that in larger ones has turned into the head statue of a lion with mutual design, in a symmetric and correspondent form that is actually a mirror-like painting.

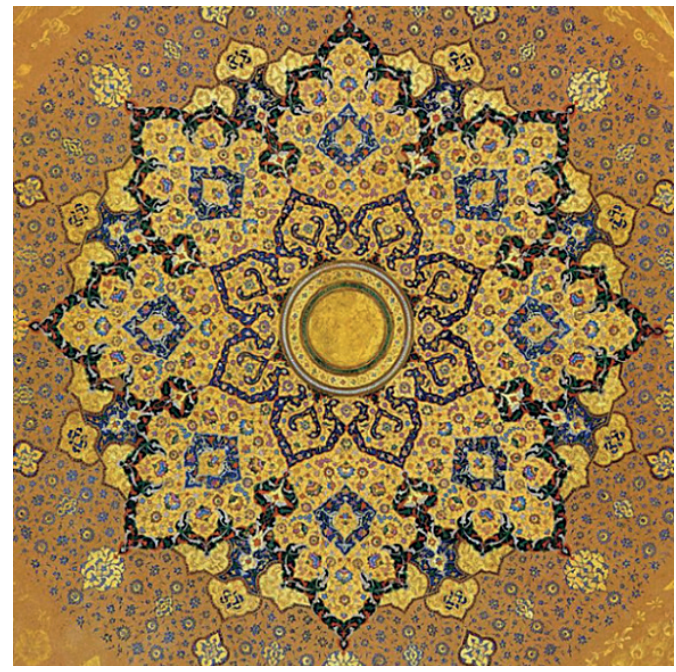

Figure 13. Shamseh octagon, Tazhib of Golshan Margha.

Source: Golestan Museum palace, Tehran.
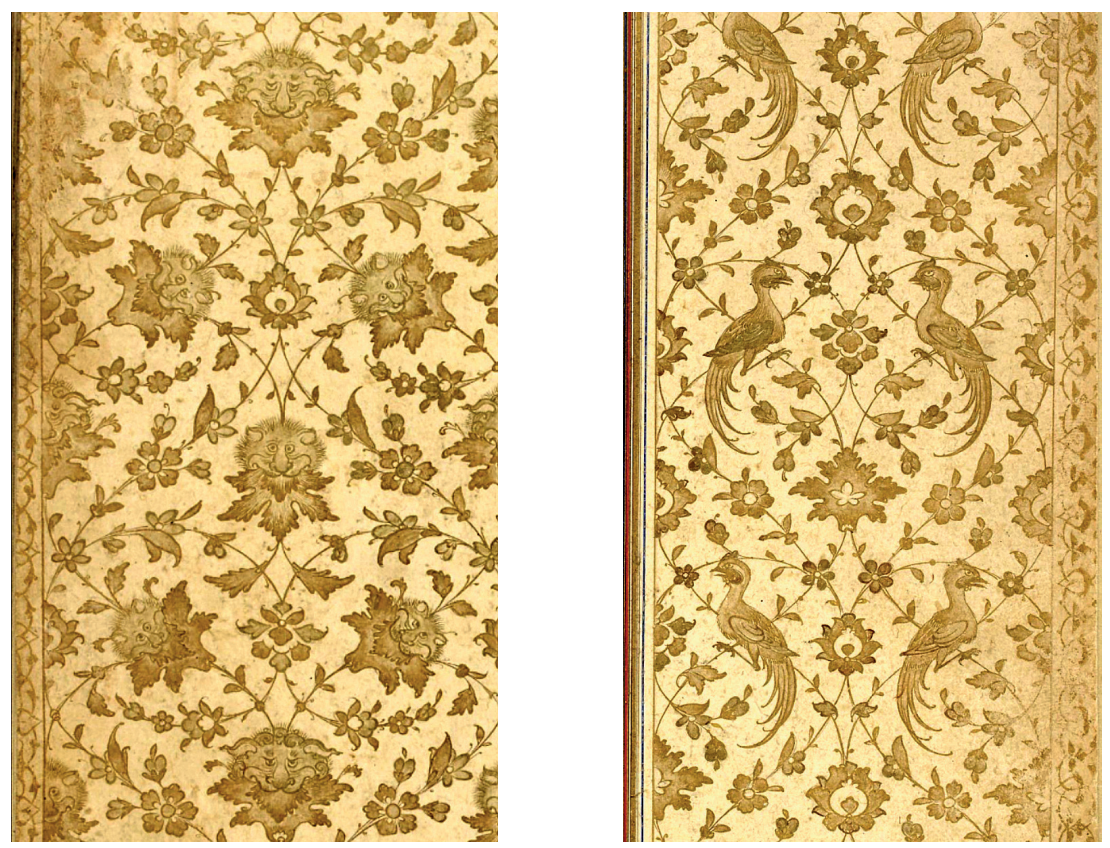

Figures 14 and 15. Tash'eer of Khamsah Tahmasbi, 2nd Tabriz Style, 946-950. f.17r/f.17v, British Museum, London. Source: www.bl.uk/manuscripts/viewer.aspx. 


\section{Miniature painting}

Pictures created in the 9th an 10th century in Islamic culture by Persian painters are distinguished from others due to the meaning, from and technical aspects. The Persian painter was himself a sophist or a mystic or at least had joined Islamic mysticism or ancient Persian wisdom through following Persian poems (Pakbaz 2014: 599). The art of illustration since its beginning until its climax in the 8th and 9th centuries show a close connection between Eastern tradition and the attitude of painters, the background of this connection constitute mystical ideas which were common in Islamic era especially in Teymori and Safavid era (Khoshnazar et al. 2010: 42).

Persian painting changes two-dimensional surface into an image of various lights and takes the viewer from the materialistic life horizon to an excellent level of awareness and makes the viewer familiar with a world beyond this world with its own positions, colors and forms (Nasr 1996: 173). Miniature painting is an illustration of the celestial origin of objects which become embodied in the Mesal world and is percepted by the artist's dream power (Nasr 1996: 176).

Two kinds of paintings are found and studied in the Negargari as brilliant visioning, the first shows the content of an object in pictures and in the second, objects are not hidden behind each other and are drawn separately in order not to be missed by viewers and be clearly observed. Both kinds are common in Persian painting especially the second one as a base principle for Persian painting (Mortazavi and Ghazizadeh 2010: 93-94).

One of these painting is related to saving Bijan from a well in Ferdowsi Shanama (Fig. 16), Persian artist has always assumed the audience to be interested in knowing every aspect of story, therefor he supposesthat we wish to observe the prisoner being hoisted. Just like people who drew him up, the painter removes part of the ground and allows us to see down the well as if looking through a window, everything is for the viewer's pleasure but far from precision and mainly for conveying the truth (Mortazavi and Ghazizadeh 2010: 94-96).

Here we are faced with the kind of brilliant visioning and it seems that the painter aims to point at the brilliance and sincerity of love between Bijan and Manijeh, and it is recognizable even in the look of soldiers in the picture as Molana says:

When the heart becomes pure and clear,
you observe the image neither water nor the earth
both you see the pattern, and also the painter
the creation (carpet of) and also the creator (carpet weaver)
(Masnavi, 1st chapter, verses no. 72-73)

In the painting called "Haron-al-rashid in bath" by Kamal-eddin behzad (Fig. 17), the best compositions of brilliant visioning type can be seen, as if the painter has cut the building longitudinally in his dream and has revealed everything, the relation of internal and external spaces attract attention to the sequence of independent but attached locations (Mortazavi and Ghazizadeh 2010: 96). 


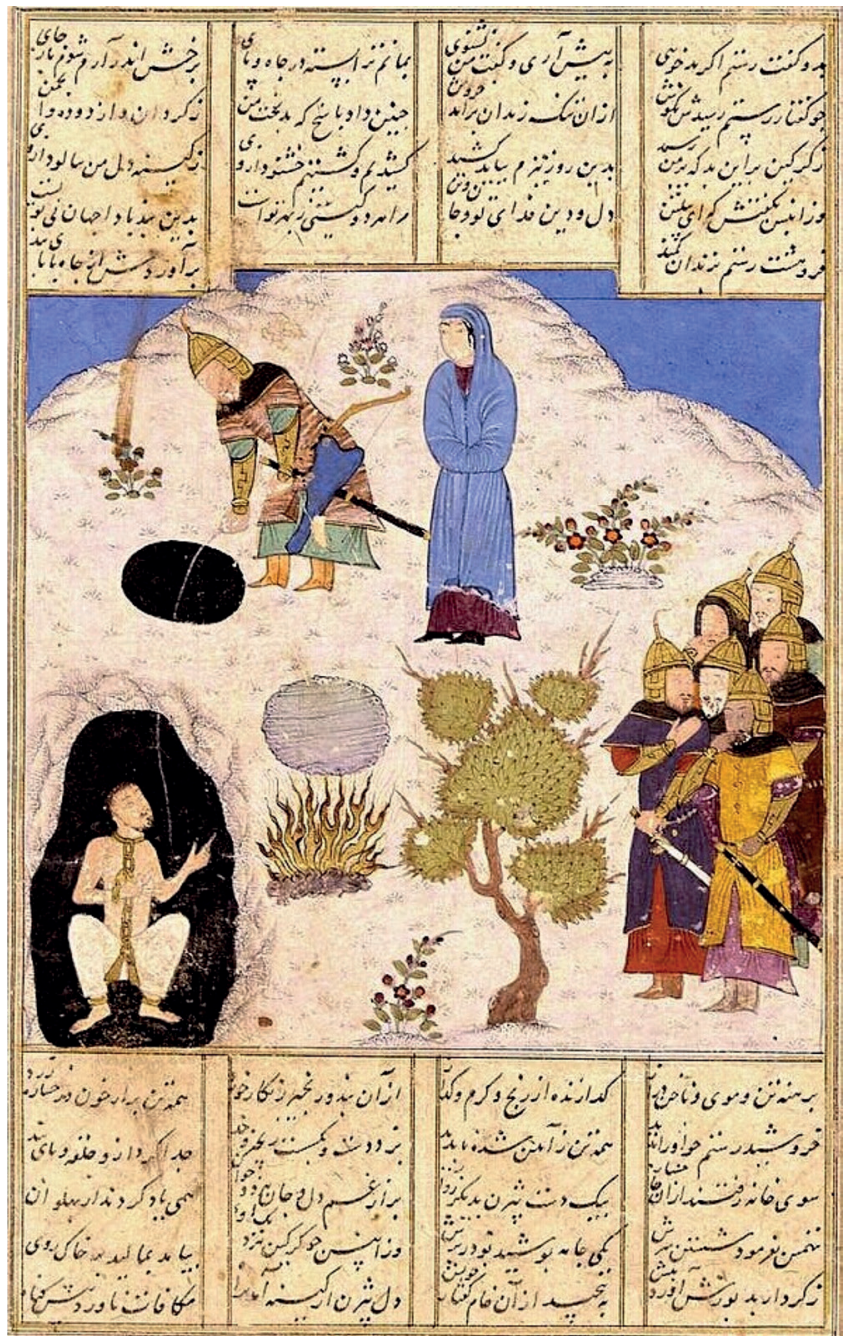

Figure 16. Rostam drops the rope for Bijan 9th century.

Ferdowsi Shahnama kept in, Miscigan Museum, Source: Hillenbrand 2000: 290.

In this kind of painting, the second principle of brilliant visioning is found, as the illustrator has shown the external space of building simultaneous with the internal space and it seems he has made a three-dimensional space. However he has merely embodied the internal or hidden parts of the building in a tandem rhythm in order it to be mirror-like and dream provoking. The dream perception of the artist in a mirror-like surfaces and images emerged inside them can be observed, Molana describes this feature in the first chapter of Masnavi:

His picture and features

What my eyes observed
Put this selfless in prison Made them get out of place! 


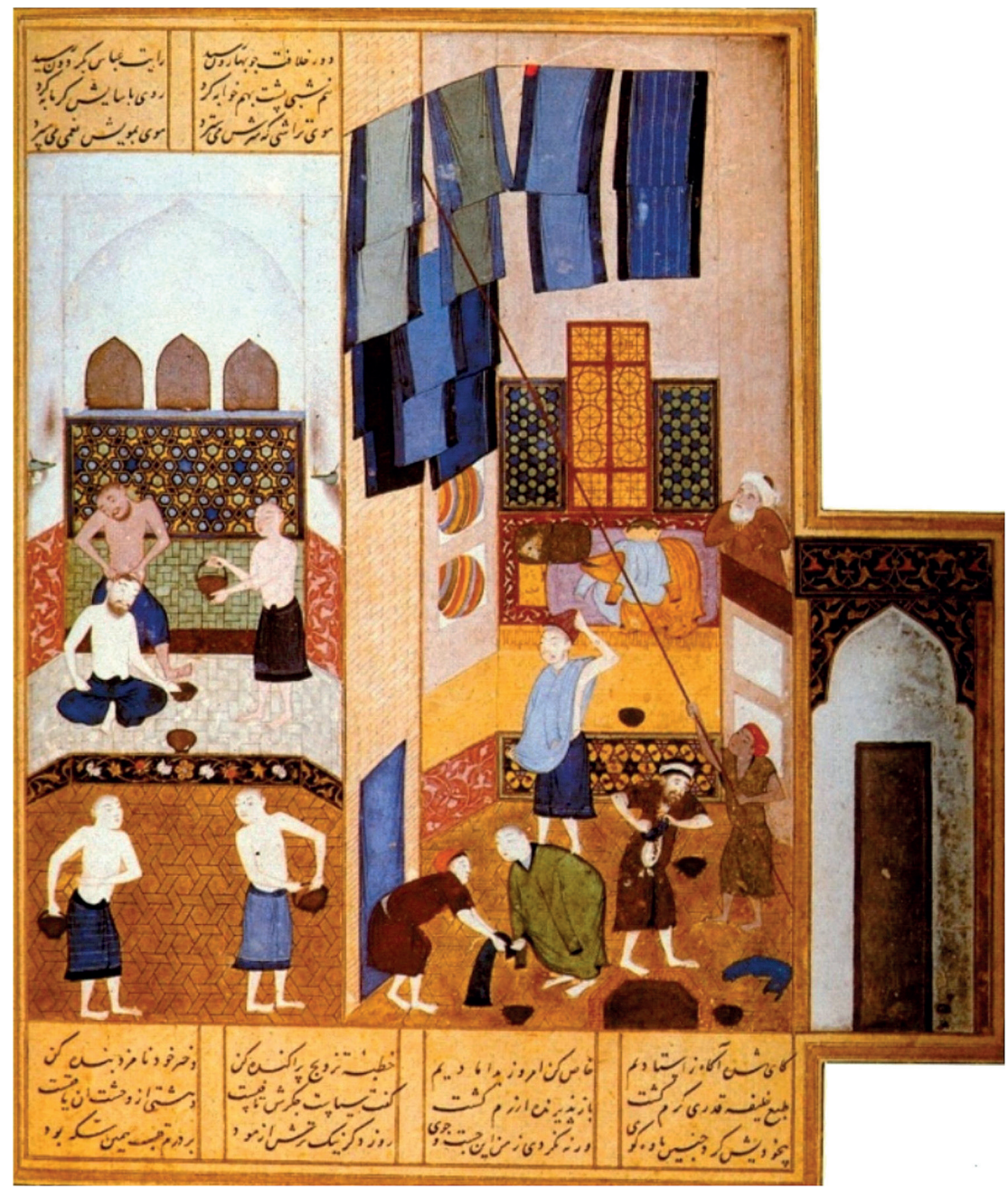

Figure 17. Haroon-al-rashid in Bath, Harat style, 899-911 by Kamal-eddin behzad, Khamsah Nizami, f.27v, kept in Britain. Source: www.bl.uk/manuscripts/viewer.aspx.

The Persian paintings are illuminated by mystical aspects of the mirror but don't reflect the image of objects, this deep semiotics which is the base of Islamic art has connected the upper and lower worlds of Molk with Malakoot and has appeared in Jannat-al-mava (paradise). The Persian painter's creativity completely coincides with the mirror aspects that reveal an incident several times with various dimensions as a hidden truth, and by removing the covers, enter the heart of a story and make a perfect exhibition of the event for the spectators. Hafez gave the below example in ghazal no.107: and the mirror watched her a hundred ways! 


\section{Islamic architecture}

Muslim artists have created some masterpieces in architecture, especially in holy buildings due to their interest and love in Allah and prophet family and Imams. The dome and wall motifs in mosques become like a mirror and prepared for excellency. Mirror-work is an affiliated decoration in Persian architecture which is used in interior design, and the art of laying regular and polygons and motifs next to each other decorates the internal spaces of buildings. This art is an innovation of Persian artists of fine art, which through numerous reflections of light from numerous pieces of mirror presents a brilliant space and superb lighting. The mirror-work artist transfers the objects to the inside of mirrors in order to create ambiguity and make an eternal world.

By producing geometric plans of vertical, horizontal and transverse lines on the walls creates effects for the moving spectator (Gardner 1999: 600), the rhythm and multiplication of the element of praise and mystical movement is in fact the holy and religious concept of decorative motifs. Decoration can be an expression of holy symbols as Henry Matis says. That is what he has learnt from the East and especially from Islam, as the main attraction of artwork and buildings lies in their decoration (Burckhardt 1990: 46). Mystics and Persian artists have used art to achieve spiritual quality of buildings and embodiment of Mesal world and have bridged the heavenly and humanistic aspects (Pourzarrin and Javani 2014: 82).

The art of mirror-work in Iran dates back to Safavid era and was first used in decoration of Divan-khane (administrative building) of Tahmasb King (930-984) in

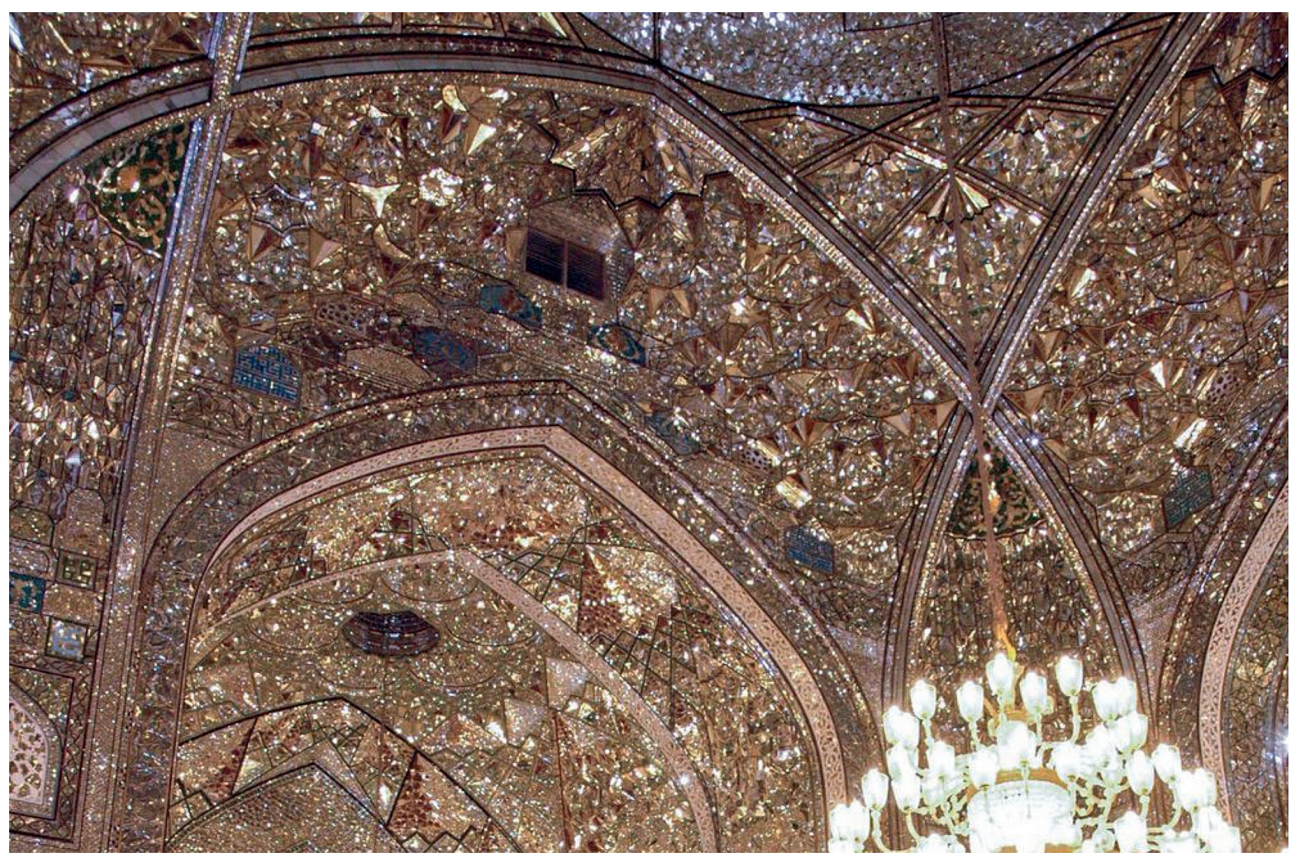

Figure 18. Close view of Dar-al-siadeh terrace-Razavi Haram, 1300. Photo by Masoud Nozari.

Source:photo.razavi.ir/portal.com/fa/content. 
Qazvin (Riyazi 1996: 11). At the beginning of 14th century the artists created two masterpieces, one is Darolsiadeh in Astan-e-qodss Razavi (Fig. 18) and the other is the mirror terrace of Hazarat-e-masoumeh (pbuh) in the city of Qom (Fig.19) (Motamen 1969: 118).

Another example of mirror-work is the holy shrine of Hazrate Abdolazim in the city of Rey and shrine of Shah-e-cheragh in Shiraz (Pourzarrin and Javani 2014: 83). In the holy buildings bright materials such as gold, steel, silver and mirror are used to reflect the light and in order to increase that, mirrors are cut into pieces and installed at various angles, in this regard the pilgrim receives a lot of light and reflections and by reflecting different angles of the face, the selfish aspects of a human being is broken. The combination of light and color especially green light increases the heavenly atmosphere of the place (Maleki 2011: 89) (Fig. 20).

The architects in Iran have produced and decorated stars and constellations with a monotheist approach in their geometric designs. This seems to the viewer like guiding a traveler by the stars; the beautiful light of the mirror in the ceilings is due to the artist's attention to Quran "Surat fussilat /1, Surat An'am /15, Surat Rahman 13, Surat Tariq /6, Surat Najm /1" (Akbari 2014: 4). The holy buildings with mirrorwork also reminds us of the unity of God and exhibit the glory and beauty of God. Hafez has talked of these features below:

one glance at the mirror that reflected your beauty created so many images in the mirror of dreams!

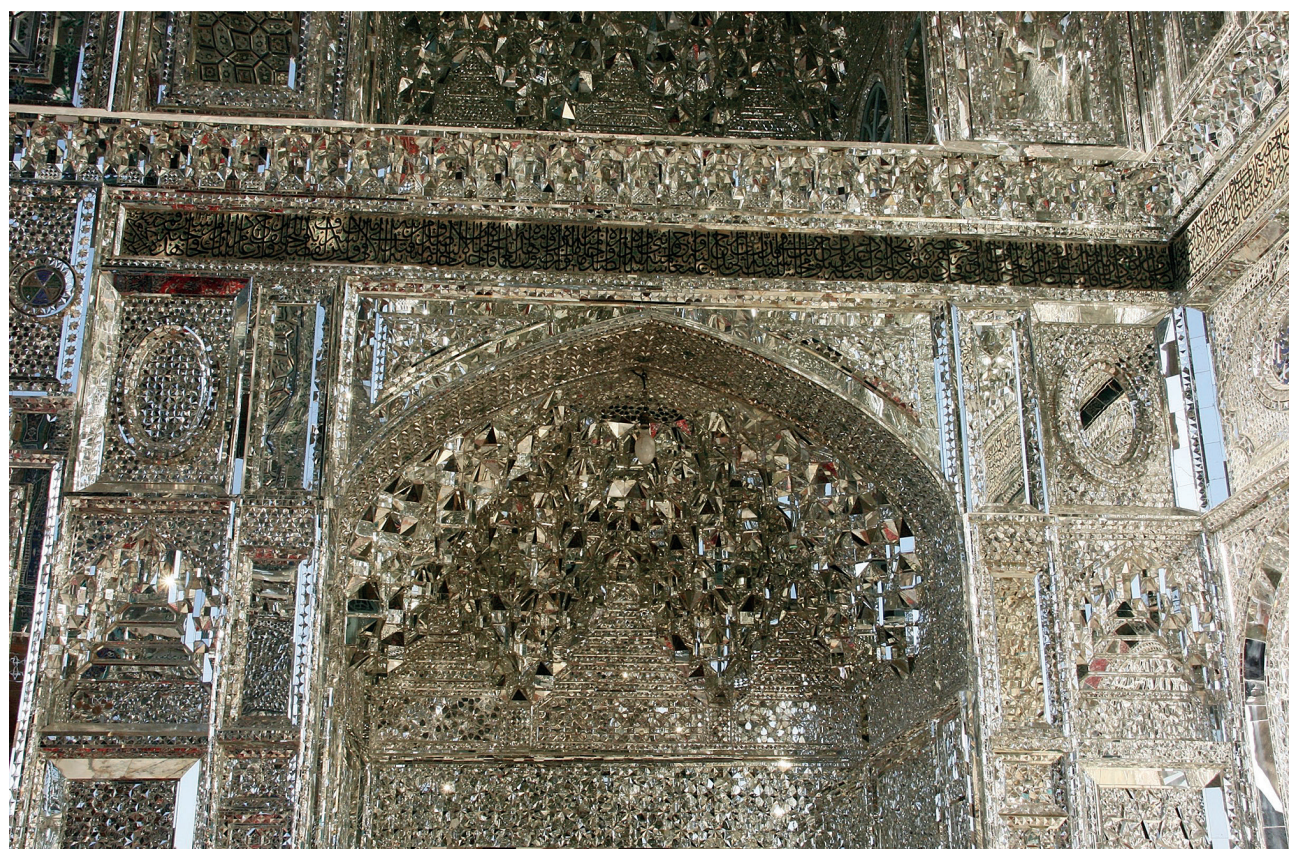

Figure 19. Hazrat-e-Masoumeh Mirror terrace, 1295. Source www.fotografia.islamoriente. 


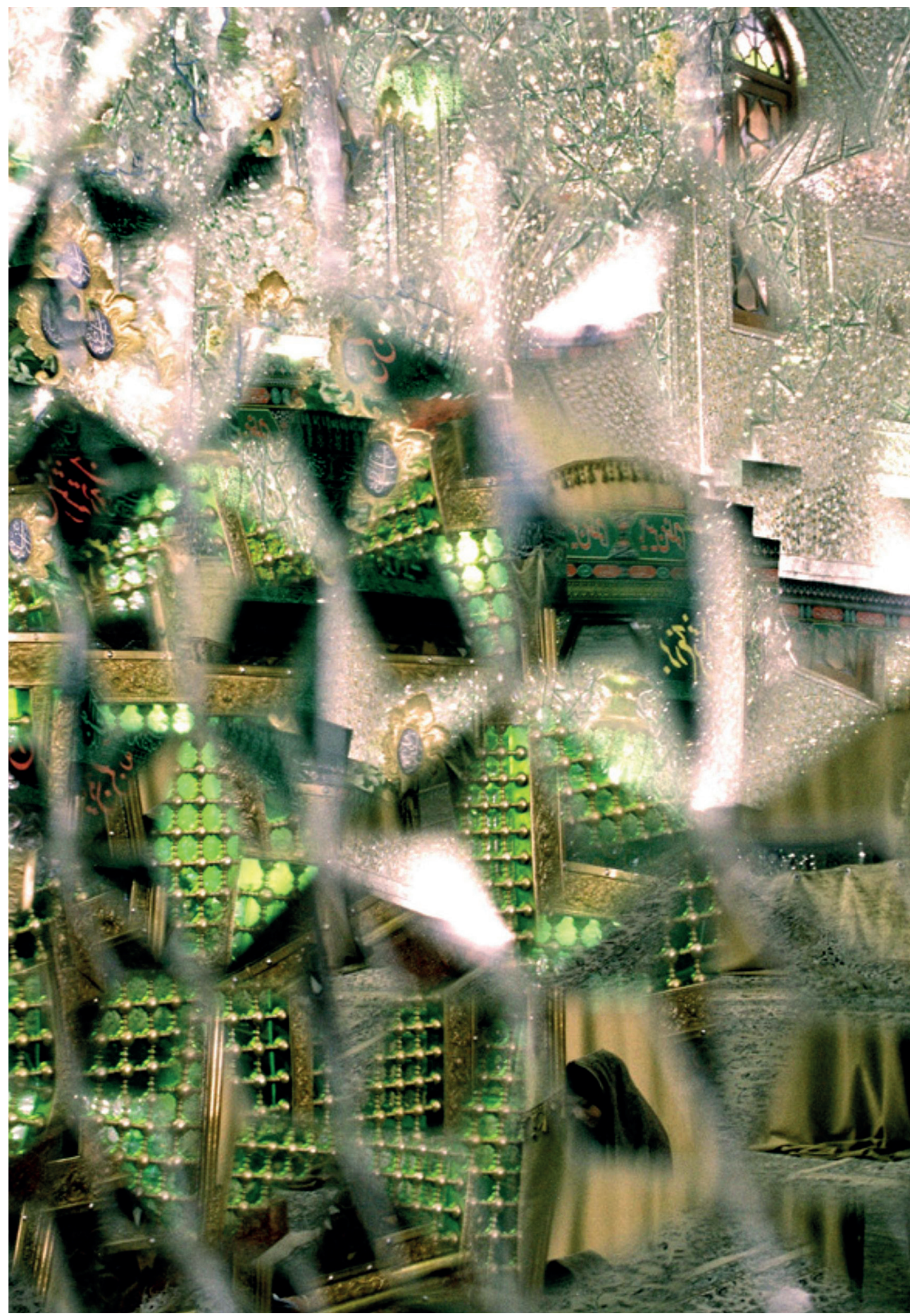

Figure 20. Mirror-work of Shah-e-cheragh, Shiraz, Zein-al abedin, 1305.

Source: Pourzarrin 2014: 85. 


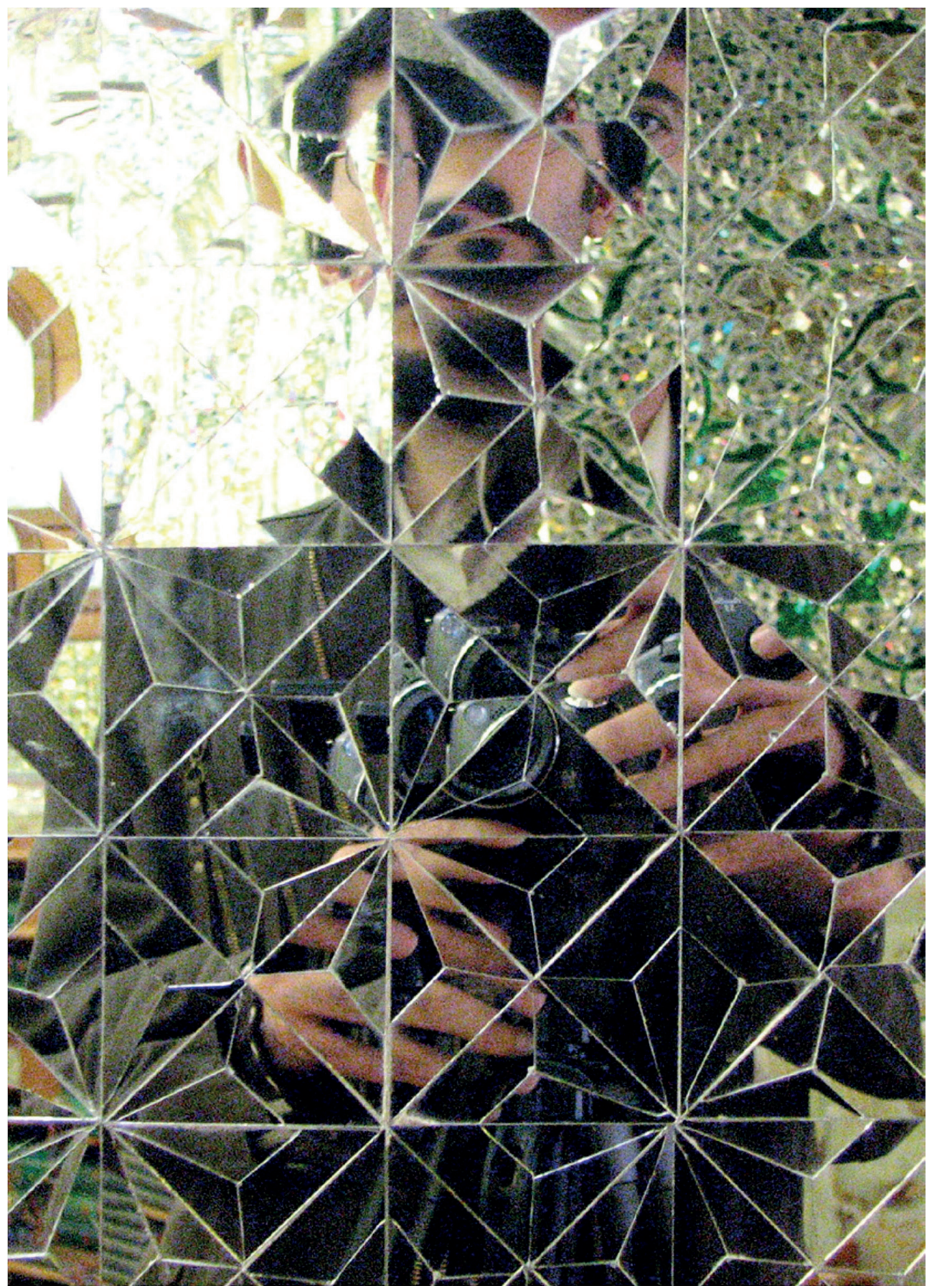

Figure 21. Mirror-work of Shah-e-cheragh, Shiraz, Zein-al abedin, 1305.

Source: Pourzarrin 2014: 86. 
The mirror breaks in architecture are numerous and designed in a way that one cannot see his face inside any of the mirrors, secondly, putting two mirrors in parallel planes and the endless repetition of images present a deep feeling, a person actually sees a mirror inside the mirrors infinitely (Fig. 21). The broken reflection of the person is also dim and semi-bright (Maleki 2011: 49). Thes aspect refers to Molana's message by gaining knowledge via a clear heart:

the clear and bright mirror resembles the heart it deserves reflecting the absolute image (of God)

This means the more sincere and clear is the heart, the more it is prepared for displaying the oracular face or the ultimate status (magham-e-lamgham) and the holy position of God, therefor the more is divine glory and passion in the follower, his wonder would be more, while feeling this love and passion some artistic creations are born (Pazouki 2003: 9). The Muslim artist breaks the mirror in order not to show a human image, creates an internalist mirror and gives spirit to it. According to Dr. Avani in book of "Wisdom and spiritual Art", for Muslim artist "the unity in plurality (monotheism) and the most important is mystery" (Aavani 1996: 340).

All these images of wine and lovers constitute a single reflection of him (Saghi) in the heart (cup of wine). Also Molana says in Divan-e-shams (Ghazal no. 2170):

Every six side of my life reflects picture of you
like a mirror when becomes polished and clear by you
However, a mirror only sees you as wide as itself
it is never big enough to show your perfect image!

\section{Conclusion}

There are mysterious patterns in many of Hafez's and Molana's ghazals and understanding them is difficult. The facts that a mystic has seen in day-dreams or night dreams and only their appearance is compliant with the apparent world, therefor the poems of mystics show their perception of the dream world truths.

The mystic is a divine mirror and reflects the image of God and displays his face, mystic poets use mirror to express the manifestation of God's names and they use mirror themes with reflection, dream and beheld concepts as reasons for the existence of Malakoot (metaphysical world) hence God's mirror is a reason for creation.

The result of the present research shows that the mirror symbol and its themes in arts except poetry have been used and these arts are influenced by them.

Also the unity in existence which originates in the mystical ideas, sees every tiny piece of the world as a mirror that displays the unique and eternal beauty of God. This important issue has greatly been applied in the Persian decorative arts and this beauty has been reflected in Islamic arts such as painting and architecture.

The Persian painter cuts into the inner layers of picture so as to act like a mirror 
and travel into the hidden truth of the story, hence the audience is driven toward the depth of the issue and flies to the ultimate dreams, this travelling invites the spectator into inside layers of his life and learn about the divine beauty.

On the other hand, the mirror-work artist in Persian architecture has shown the monotheist approach in the geometrical designs and has used cut mirrors to boost the attraction of the space in a way that countless rays reach the viewer, and he feels the unity while entering the holy shrines and mosques and becomes inspired by the purity of mirror and consequently invited to the purity and sincerity of God.

Address:

Golnar Alibabaei

Iran. Alborz.

Karaj. Sepah Square. Fajr Square

South Islamic Republic Boulevard. West Sixth Street

Maryam Building. No. 10. Unit 3

E-mail: galibabaei@gmail.com

Tel.: 00989351348834

\section{References}

The Holy Quran.

Akbari, Fatima (2014) “Qibla's place in honor of Islamic art and architecture”. International Congress of Religious Culture and Thought. Qom: Iran.

Attar Nishaburi and Faride-addin Mohammad (1992) Divan Attar. 6th ed. Ed. by Taghi Tafazolli. Tehran: Scientific and Cultural Publications.

Awani, Gholamreza (1996) Spiritual wisdom and art. Tehran: Gaross Publications.

Babaei, Ali (2012) Endless passwords mirrors. Tehran: Moly.

Balkhi, Jalal-addin (2004) Masnavi manavi. Nicholson correction. Hassan Lahouti's translation and research. Tehran: Ghatreh.

Bidel Dehlavi, AbdulQader (2007) Divan Bidel Dehlavi. Correction by Akbar Behdarvand. Tehran: Negah Publications.

Burckhardt, Titus (1990) Sacred art: principles and methods. Translated by Jalal Sattari. Tehran: Soroush.

Dehkhoda, Ali Akbar (1995) Dictionary. Tehran: Amir Kabir.

Fehervari, Geza (2000) Ceramics of the Islamic world (in the Tariq Rajab Museum). London and New York: IB. Tauris Publishers.

Gardner, Helen (1999) Art through ages. translated by Mohammad Taghi Faramarzi. Tehran: Agah.

Halimi, Mohammad Hossein (2011) Aesthetics of the line in Isfahan Jameh Mosque. Tehran: Ghadyani. Hosseini, Saleh (1990) Literary reform. Tehran: Niloofar.

Jami, Abdolrahman (1982) Haft orang. 3rd ed. Ed. by Morteza Modarres Gilani. Tehran: Saadi Publishing.

Kakayi, Qasim (2001) "Unity of existence: experience, interpretation, allegory". The Quarterly of Religious Thought 8-9, 79-121. 
KamaliZadeh, Taherah (2013) The metaphysical foundations of art and beauty according to Shahabaddin Sohrawardi. Tehran: Academy of Art.

Khaje Shams-addin Mohammad, Hafez Shirazi (1995) Divan Hafez. 5th ed. Ed. by Qazvini and Ghani. Tehran: Asatir.

Khalil-Allahi, Shahla and Ghafar Borjsaz (2011) "The readings of the existential unity of the mirror in Bidel's poems". Literary Textual Studies 49, 53-72.

Khoshnazar, Sayyed Rahim, et al. (2010) “Muslim mystics' view of light”. Fine Arts 42, 5-14.

Maleki, Morteza (2011) A new look at Islamic architecture. Tehran: Royan Pajouh.

Monshi Qomi, Qazi MirAhmad (1973) Golestan art by Ahmad Soheili Khansari. Tehran: Foundation for Iranian Culture.

Mortazavi, Marjan and Khashayar Ghazizadeh (2010) "Transparent nose in contemporary imagery of Iran and the world". Negareh 16, 91-101.

Mosharraf, Mary (2004) "Mirrors and harp in Rumi”. Persian Language and Literature 45-46, 81-106.

Motamen, Ali (1969) Guide or history of Astan Qods Razavi. Tehran: Astan Qods.

Nasiri, Mohammad (2010) "The personal unity of being in the mirror of mystical parables". The Mirror of Knowledge 23, 27-52.

Nasr, Sayyed Hossein (1996) Islamic art and spirituality. Tehran: Hekmat.

Pakbaz, Royein (2014) Encyclopedia of art. Tehran: Contemporary Culture.

Pazouki, Shahram (2003) "Mystical foundations of art and beauty in Islam: with reference to Masnavi". Fine Arts 15, 4-11.

Pope, Arthur Epham (2008) Masterpieces of Persian art. Written by Parviz Natel Khanlari. Tehran: Scientific and Cultural.

Pourzerrin, Reza and Asghar Javani (2014) "A comparative study of visual signs in Iranian mirror and photocollage art". Fine Arts 4, 81-92.

Pournamdarian, Taghi (1985) Secrets and Ramsey stories in Persian literature. Tehran: Scientific and Cultural Publications.

Riyazi, Mohammadreza (1996) Culture and forms of Iranian idioms. Tehran: Al-Zahra University.

Roshan, Amin (2007) “The mirror symbol in Rumi's thought”. Religion and Mysticism 11, 107-121.

Saeb Tabrizi, Mohammad Ali (1991) Poems divan. 6 vols. Ed. by Mohammad Ghahreman. Tehran: Scientific and Cultural.

Sarrami, Ghadamali (2009) "The mirror of manifestation in mystical literature". Special Journal of Mysticism 24, 33-74.

Sarfi, Mohammadreza (2003) "Introduction to symbolism in literature". Journal of Culture 46-47, 159-177.

Tabarsi, Abu Ali Fazl (2011) Majma Al-Bayan fi Tafsir al-Quran. Transl. by Mohammad Bistouni. Tehran: Astan Quds Razavi.

Tadayyon, Mehdi (2015) "Plenteous poetry and mysticism". Dordari (Scientific and Special Issue) 17, $39-58$. 